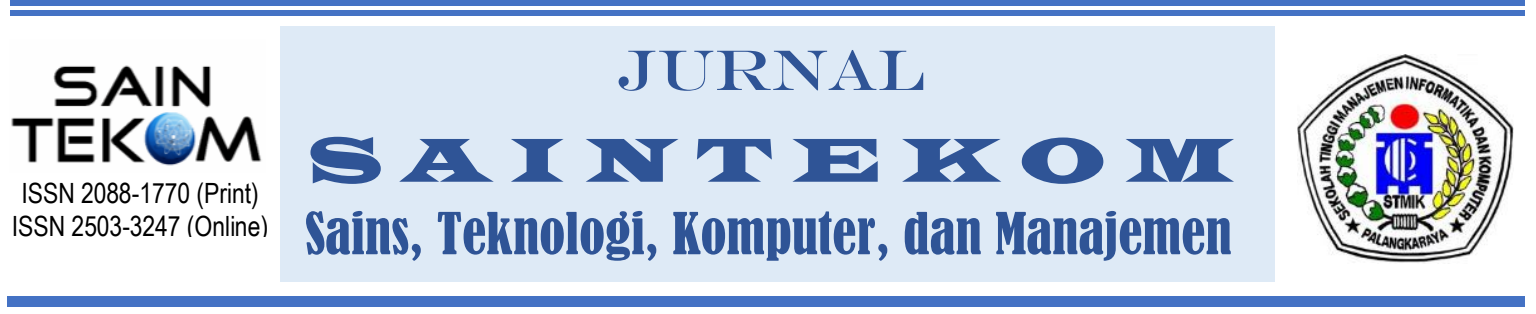

\title{
E-LEARNING BERBASIS WEBSITE PADA SLBN 1 PALANGKA RAYA
}

\author{
Admi Rut Sinana ${ }^{1}$, Abertun Sagit Sahay ${ }^{2}$ \\ 1) Program Studi Magister Ilmu Komputer Universitas Brawijaya \\ Jl. Veteran, Ketawanggede, Kec. Lowokwaru, Kota Malang, Jawa Timur \\ ${ }^{2}$ Program Studi Teknik Informatika Universitas Palangka Raya \\ Jl. Yos Sudarso, Palangka, Kec. Jekan Raya, Kota Palangka Raya, Kalimantan \\ Tengah \\ Email: admirut@gmail.com, abertun@gmail.com
}

\begin{abstract}
E-learning of SMPLB and SMALB on SLBN 1 Palangka Raya was built for students who have special needs in terms of hearing and moving. Teachers in the classroom more often use video and picture media, this is certainly not a problem when students are in class, but when students are at home and want to repeat the learning, of course this will be an obstacle. Based on thats problems, it is expected this e-learning of SLBN 1 Palangka Raya can facilitate the teaching and learning process. The design method of this e-learning uses of the Waterfall Software Development Method according to Sommerville (2011). The testing method carried out on the e-learning is a blackbox testing. This website can manage the accounts of each user, provide academic information, provide reading references and provide other learning information.
\end{abstract}

Keyword: e-learning, SMPLB 1 Palangka raya, pembelajaran

\begin{abstract}
ABSTRAK
E-learning SMPLB dan SMALB di SLBN 1 Palangka Raya dibangun untuk siswa berkebutuhan khusus dalam hal pendengaran dan gerak. Guru di kelas saat mengajar lebih sering menggunakan media pembelajaran berupa video dan gambar. Hal ini tentunya tidak menjadi masalah ketika siswa berada di dalam kelas, namun ketika siswa berada di rumah dan ingin mengulang kembali pembelajaran, tentunya hal tersebut akan menjadi kendala. Berdasarkan permasalahan sebelumnya maka diharapkan e-learning pada SLBN 1 Palangka Raya ini dapat mempermudah keterbatasan dalam proses belajar mengajar tersebut. Metode perancangan e-learning ini menggunakan Metode Pengembangan Perangkat Lunak Waterfall menurut Sommerville (2011). Metode pengujian yang dilakukan pada e-learning ini adalah pengujian blackbox. Website ini dapat mengelola akun masing-masing pengguna, memberikan informasi akademik, memberikan referensi bacaan dan memberikan informasi pembelajaran lainnya.
\end{abstract}

Kata Kunci: e-learning, SMPLB 1 Palangka raya, pembelajaran 


\section{PENDAHULUAN}

Sekolah Luar Biasa Negeri 1 Palangka Raya adalah sekolah satu atap terdiri dari TKLB, SDLB, SMPLB, dan SMALB. Sekolah satu atap ini terdapat anak-anak dengan kekurangan fisik maupun mental atau dapat disebut dengan Anak Berkebutuhan Khusus (ABK). Seorang Anak Berkebutuhan Khusus (ABK) merupakan anak dengan karakteristik khusus yang berbeda dengan anak pada umumnya yang dapat terlihat dari ketidakmampuan mental, emosi atau fisik (Hartie, 2016).

$$
\text { Berbagai macam Anak }
$$

Berkebutuhan Khusus (ABK) yang terdapat pada SLBN 1 Palangka Raya ini ada berbagai macam antara lain seperti Tuna Netra, Tuna Rungu, Tuna Grahita, Tuna Daksa, dan Tuna Laras. Berdasarkan karakteristik dan hambatan tersebut, seorang Anak Berkebutuhan Khusus (ABK) memerlukan bentuk pelayanan pendidikan khusus yang disesuaikan dengan kemampuan dan potensi mereka. Seperti contohnya pada anak dengan kategori Tuna Rungu dimana anak dengan kebutuhan khusus ini kurang atau bahkan tidak dapat mendengar dan berbicara sehingga sistem pengajarannya lebih menggunakan indra penglihatan. Guru di kelas akan mengajar dengan meggunakan bahasa isyarat dalam berkomunikasi serta didukung dengan tulisan, gambar maupun gambar yang bergerak (video). Anak dengan kebutuhan ini memang tidak dapat mendengar dan berbicara namun dapat menggunakan indra penglihatan sebagai sarana penerima informasi pengganti kekurangan dalam indra pendengaran selain itu mereka bisa memahami informasi dalam sebuah kata maupun kalimat dengan kemampuan penglihatannya.

Berbeda pula dengan siswa berkebutuhan khusus lain yaitu dalam hal gerak, Tuna Daksa memiliki gangguan gerak yang disebabkan oleh kelainan neuro-muskular dan struktur tulang yang bersifat bawaan, sakit atau akibat kecelakaan, termasuk Celebral Palsy, amputasi, polio, dan lumpuh (Hartie, 2016). Tingkat gangguan pada Tuna Daksa terbagi atas tiga yaitu yang pertama adalah ringan dimana memiliki keterbatasan dalam melakukan aktivitas fisik tetap masih dapat ditingkatkan melalui terapi, yang kedua merupakan sedang dimana memiliki keterbatasan motorik dan mengalami gangguan koordinasi sensorik, dan yang ketiga berat dimana ia memiliki keterbatasan total dalam gerakan fisik dan tidak mampu mengontrol gerakan fisik. 
Dalam pengajaran di kelas sendiri anak dengan keterbatasan gerak ini sama dengan orang biasa, karena kekurangan Tuna Daksa pada siswa SMPLB maupun SMALB pada SLBN 1 Palangka Raya biasanya adalah kurangnya kemampuan dalam aktivitas fisik yang lebih menggunakan kekuatan kaki atau tubuh bagian bawah namun untuk tubuh bagian atas seperti tangan dan bagian fisik lain dan juga mental dapat digunakan seperti orang normal biasanya.

Proses belajar mengajar di SMPLB dan SMALB ini siswa yang mengalami kekurangan fisik dalam hal mendengar maupun bergerak akan dijadikan dalam satu kelas yang bersamaan. Materi pengajaran akan disampaikan dalam bentuk materi yang dapat dilihat secara visual bagi siswa dengan kebutuhan khusus dalam hal mendengar dan bagi siswa yang berkebutuhan khusus dalam hal gerak akan diberikan materi ajar yang dapat dilihat maupun didengar oleh siswa tersebut.

Hal lain yang menjadi permasalahan adalah dimana ketika pembelajaran tersebut diberikan melalui gambar maupun video yang diputar di kelas lalu siswa ataupun orang tua/wali dari siswa tersebut ingin melatih atau mengulang kembali pembelajaran yang siswa telah terima sebelumnya di kelas, tentunya hal ini akan menjadi suatu keterbatasan pembelajaran yang dapat dilakukan siswa karena pembelajaran tersebut yaitu gambar maupun video hanya tersedia saat guru mengajar di kelas.

Penggunaan e-learning dalam kegiatan belajar mengajar sendiri merupakan usaha membuat transformasi proses belajar mengajar yang ada di sekolah ke dalam bentuk digital. Media pembelajaran online (e-learning) dapat diartikan sebagai media yang dilengkapi dengan perangkat elektronika yang dapat dioperasikan oleh pengguna untuk dapat mengendalikan dan mengakses apa yang menjadi kebutuhan dalam pembelajaran secara online (Arnesti, 2015).

Penelitian terdahulu yang dilakukan di SMPLB 1 Palangka Raya merancang sebuah e-learning khusus hanya bagi siswa yang berada pada tingkatan SMPLB dengan kelas Tuna Rungu yang masih dibatasi pada pemberian materi berupa dokumen tertulis seperti word maupun pdf (Admi, 2018)

Oleh karena itu, pada penelitian ini Website E-Learning SLBN 1 Palangka Raya dikembangkan untuk 
dapat menjadi media yang memfasilitasi guru dan juga siswa maupun orang tua dalam proses pembelajaran dan penyampaian hal-hal yang penting dalam pembelajaran tidak hanya bagi SMPLB namun juga bagi SMALB serta dalam bentuk pemberian materi yang tidak hanya terbatas pada materi dokumen tertulis melainkan juga dalam bentuk video maupun gambar.

\section{METODE}

Metode penelitian untuk membuat "Website E-Learning SLBN 1 Palangka Raya", yaitu melakukan penelitian dengan studi kepustakaan, literatur, referensi seperti mempelajari buku dan informasi dari internet yang berhubungan dengan proses pembuatan website ini. Selain itu juga dengan melakukan studi konsultasi dan diskusi yaitu berupa tanya jawab dengan dosen pembimbing ataupun orang-orang yang berpengalaman dalam pembuatan website.

Metode pengembangan yang digunakan dalam pembuatan Website ELearning SLBN 1 Palangka Raya ini adalah metode pengembangan Waterfall menurut Sommerville (2011) dengan tahap-tahap sebagai berikut.

a. Requirements Analysis and Definition (Analisis dan Definisi Kebutuhan)
Tahap ini akan menganalisis kebutuhan yang diperlukan oleh guru, siswa dan orangtua sebagai user dalam pembuatan Website ELearning SLBN 1 Palangka Raya ini, guna mencari pilihan dan solusi fitur apa yang akan dirancang. Pada tahap analisis ini juga dilakukan pembuatan Flowchart.

b. System and Software Design (Perancangan sistem dan Perangkat Lunak)

Tahap ini berguna untuk melakukan pendesainan web interface yang akan dibuat, pada tahap ini rancangan akan disesuaikan dengan kebutuhan pengguna.

c. Implementation and Unit Testing (Implementasi dan pengujian unit).

Penulisan program dengan menggunakan pemrograman yaitu HTML, PHP, CSS, Bootstrap, Javascript dan MySQL sebagai perangkat untuk pembuatan databasenya. Untuk perancangan perangkat lunak direalisasikan sebagai serangkaian program atau unit program. Pengujian unit melibatkan verifikasi bahwa setiap unit telah memenuhi spesifikasinya.

d. Integration and System Testing (Integrasi dan Pengujian Sistem). Setelah didesain, dan dilakukan 
penulisan program, maka rancangan website tersebut diimplementasikan. Hasil dari implementasi tersebut maka yang akan dilakukan uji coba terlebih dahulu, jika ada kesalahan, maka akan kembali ke metodologi sebelumnya yaitu pembuatan Kode Program Web. Metode testing yang digunakan pada pembuatan Web ini adalah Metode Blackbox.

\section{HASIL DAN PEMBAHASAN}

Studi kasus yang dilakukan pada SMPLB dan SMALB khusus bagi kelas VII, VII, IX Tuna Rungu dan X, XI, XII Tuna Rungu di SLBN 1 Palangka Raya. Website ini berfungsi untuk menyampaikan materi pembelajaran selama di kelas bukan untuk pemberian tugas melalui website yang hasil tugasnya harus dikumpulkan melalui website sehingga tidak ada pengumpulan tugas yang dilakukan melalui website ini.

Penelitian ini dimulai dengan melakukan analisis pengguna dan menganalisis sistem. Bagian analisis pengguna akan dimulai dengan identifikasi kegiatan dan proses bisnis yang dilakukan oleh masing-masing pengguna. Pengguna website ini yaitu super admin, admin, guru, siswa, orang tua dan pengunjung.

Hal tersebut dilakukan dengan menganalisis kebutuhan yang diperlukan oleh super admin, admin, guru, siswa dan orang tua serta pengunjung sebagai pengguna dalam pembuatan website, E-Learning SLBN 1 Palangka Raya ini, guna mencari pilihan dan solusi fitur apa yang akan dirancang. Pada tahap analisis ini juga dilakukan pembuatan Flowchart untuk mengetahui bagaimana sistem dari $e$ learning ini akan berjalan.

Flowchart ini sendiri adalah untuk menggambarkan serta menyederhanakan rangkaian proses atau prosedur sehingga mudah dipahami dan mudah dilihat berdasarkan urutan langkah dari suatu proses. Flowchart merupakan suatu bagan (chart) yang menunjukkan alir (flow) di dalam suatu program atau prosedur sistem secara logika (Alwinda, 2016).

Setiap pengguna tersebut dapat menggunakan website dengan login untuk nantinya dapat masing-masing menikmati fitur yang disediakan. Khusus bagi pengguna dengan identitas Pengunjung. Pengunjung disini dapat menggunakan website namun dengan fitur-fitur yang lebih terbatas dibanding 
dengan pengguna sebagai siswa maupun orang tua.

Gambar 1 merupakan salah satu analisis yang dilakukan pada salah satu pengguna yaitu pengujung. Nantinya pengunjung hanya akan dapat melihat lebih sedikit fitur dibanding hak akses lain yang mengharuskan mereka login terlebih dahulu.

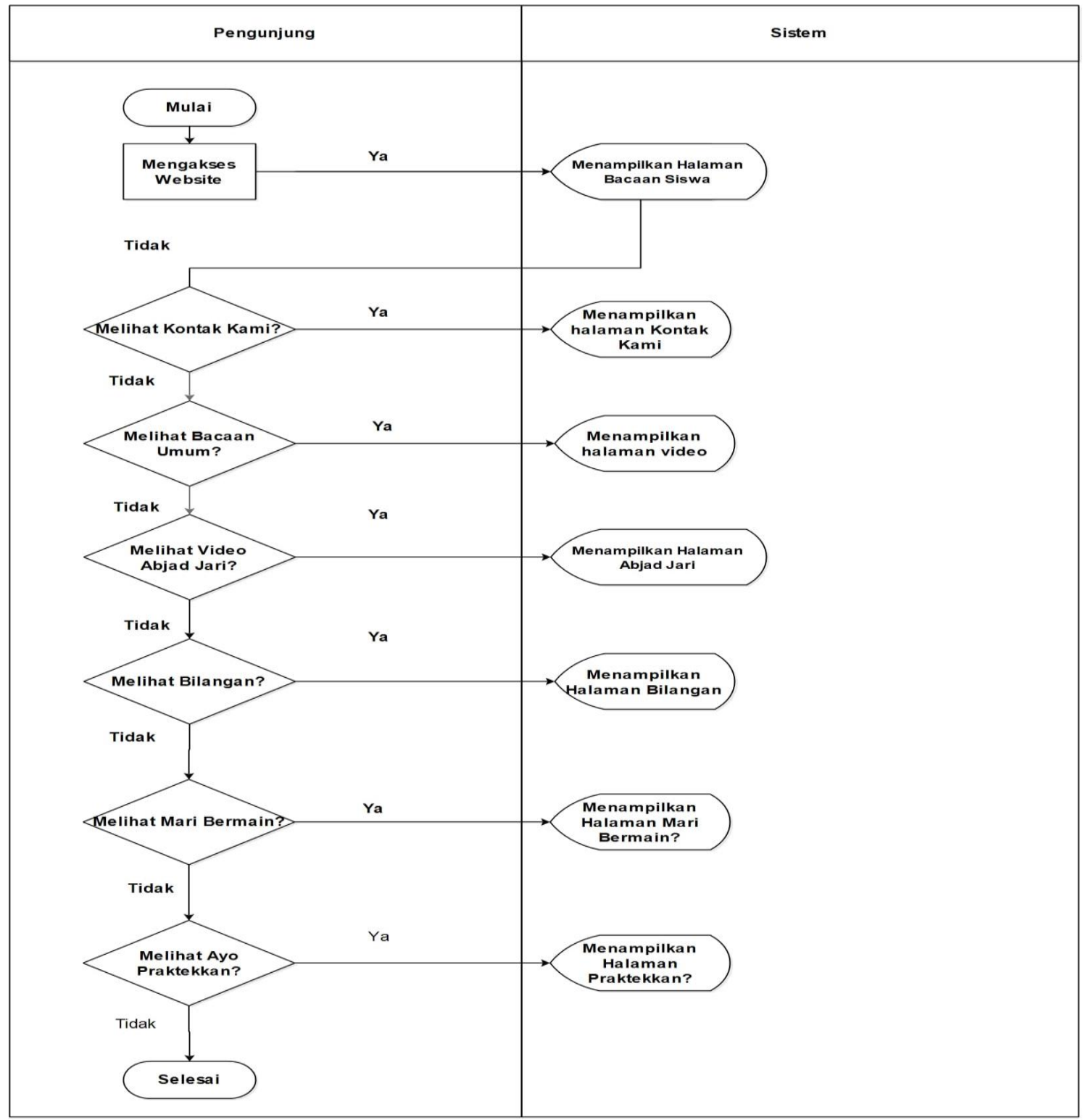

Gambar 1 Flowchart Pengunjung

Setelah sebelumnya logika, penulis juga menggunakan menggunakan flowchart yang Diagram Konteks dalam membuat merupakan suatu bagan (chart) yang desain dari sistem yang akan dibangun. menunjukkan alir (flow) di dalam suatu Diagram Konteks ini sendiri memiliki program atau prosedur sistem secara 
fungsi untuk menggambarkan proses dari sistem.

Diagram Konteks merupakan tingkatan tertinggi dalam diagram aliran data dimana hanya memuat satu buah proses yang akan menunjukkan sistem secara keseluruhan baik seluruh input ke sistem atau output dari sistem. Dapat dikatakan jika diagram ini yang akan mencakup masukan-masukan dasar, sistem umum dan keluaran. Diagram ini juga yang terdiri dari hanya dari satu proses dan menggambarkan ruang lingkup suatu dari sistem.

Hal ini juga selaras dengan pernyataan Alwinda (2016) dimana fungsi dari Diagram Konteks yaitu merupakan alat pembuatan model yang memungkinkan profesional sistem untuk menggambarkan sistem sebagai suatu jaringan proses fungsional yang dihubungkan satu sama lain dengan alur data, baik secara manual maupun komputerisasi, alat perancangan sistem yang berorientasi pada alur data dengan konsep dekomposisi dapat digunakan untuk penggambaran analisa maupun rancangan sistem yang mudah dikomunikasikan oleh profesional sistem kepada pemakai maupun pembuat program.

Diagram Konteks ini dirancang dengan memperhatikan masukan yang dibutuhkan oleh sistem dan keluaran yang dihasilkan oleh sistem. Diagram Konteks ini memiliki enam entitas luar yaitu Super Admin (Kepala Sekolah), Admin (Wakasek Humas), Guru, Siswa, Orangtua dan Pengunjung.

Entitas-entitas tersebut yang akan memberikan data yang dibutuhkan sistem dan menerima informasinya. Berikut adalah Diagram Konteks dari $e$ learning yang dibangun dapat dilihat pada Gambar 2 berikut. 


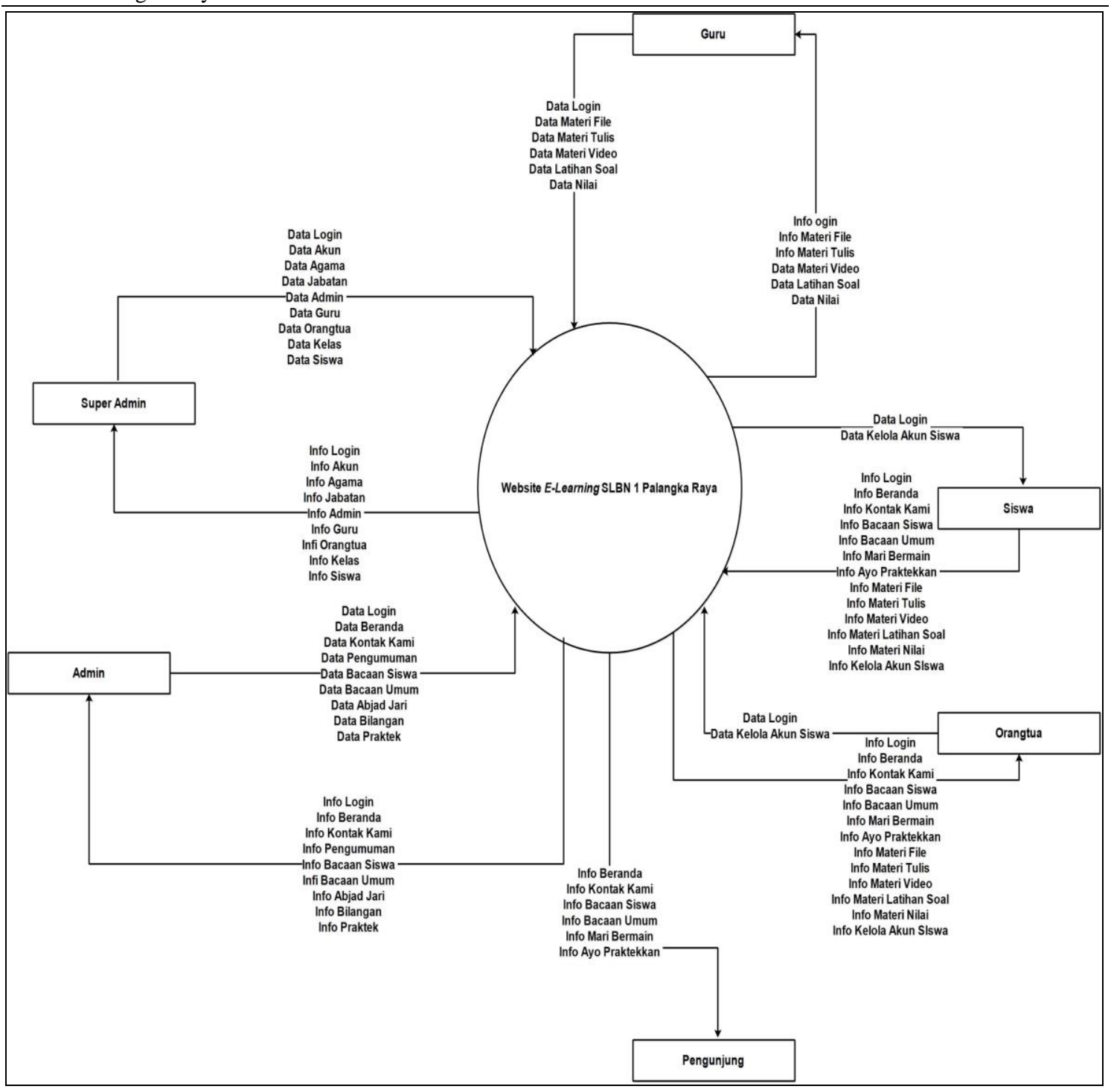

Gambar 2 Diagram Konteks Website E-Learning SLBN 1 Palangkaraya

Selanjutnya juga dibuat desain yang nantinya akan diimplementasikan dalam website yang akan dibuat yaitu seperti terlihat pada Gambar 2.

Gambar 2 merupakan rancangan atau desain tampilan beranda atau halaman utama dari website e-learning yang akan dibangun. Terdapat tampilan dimana tersedia berbagai menu yang dapat diakses oleh pengunjung, seperti menu Bacaan Materi dan menu lainnya.

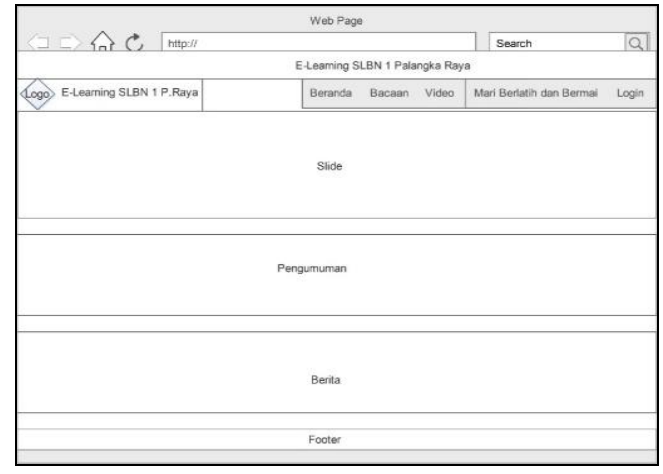

Gambar 3 Rancangan Tampilan Halaman Utama Website E-Learning

Setelah perancangan data maupun tampilan yang dibuat 
sebelumnya maka akan diimplementasikann website e-learning secara garis besar yang akan dibuat tersebut sebagai berikut.

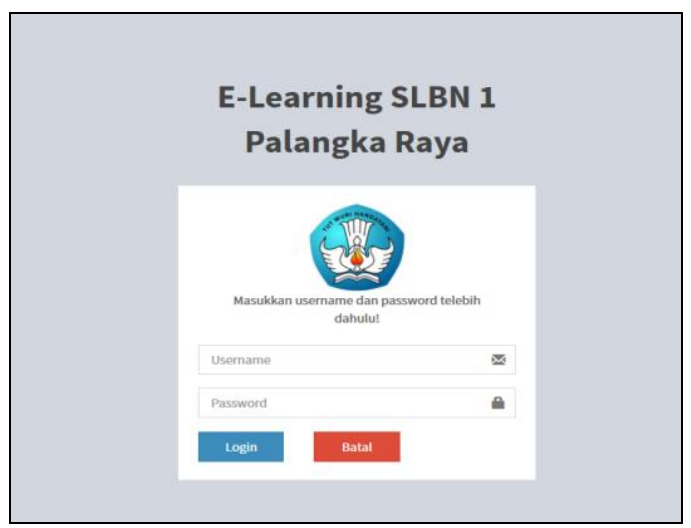

Gambar 4 Tampilan Halaman Login Super Admin, Admin, dan Guru

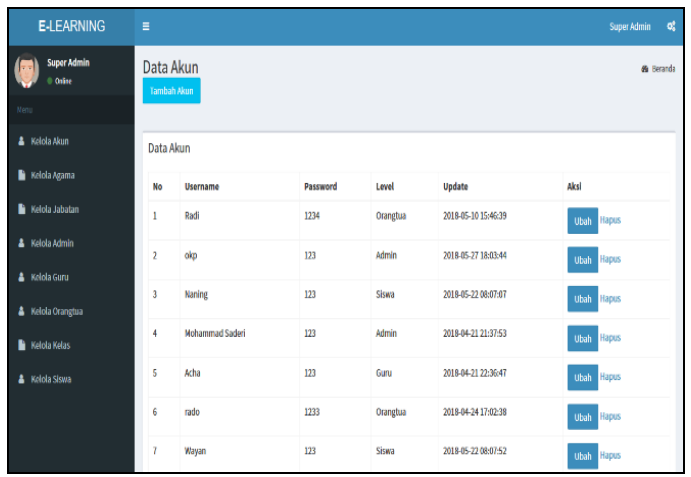

Gambar 5 Tampilan Halaman Kelola Akun Pengguna Website E-Leaarning

Gambar 4 merupakan tampilan dari halaman login dari super admin. Pada Gambar 5 super admin dapat mengelola akun dari masing-masing pengguna yang terdaftar pada website elearning SLBN 1 Palangka Raya.

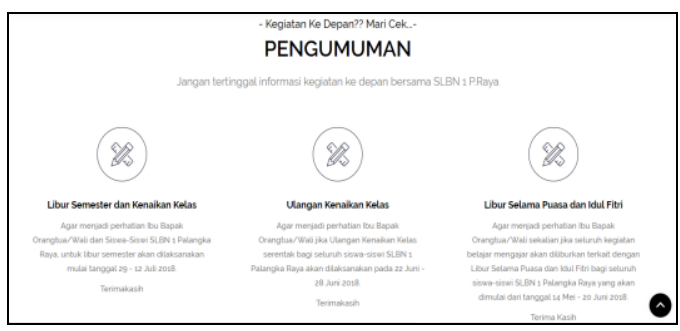

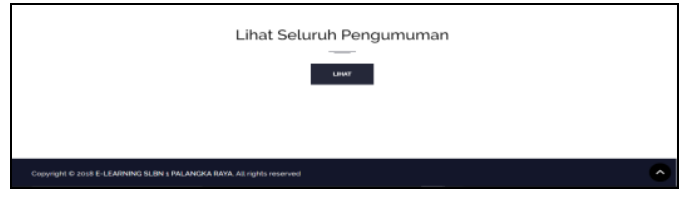

Gambar 6 Tampilan Halaman Beranda $E$ Learning

Gambar 7 merupakan tampilan dari salah satu halaman utama yang dapat dilihat oleh pengunjung. Gambar 7 merupakan salah satu halaman yang dapat diakses oleh pengunjung yaitu halaman bacaan, dimana pada halaman ini pengunjung disuguhkan bacaan ringan dari bacaan cerita dongeng yang bertujuan sebagai media hiburan maupun juga sarana berlatih membaca.

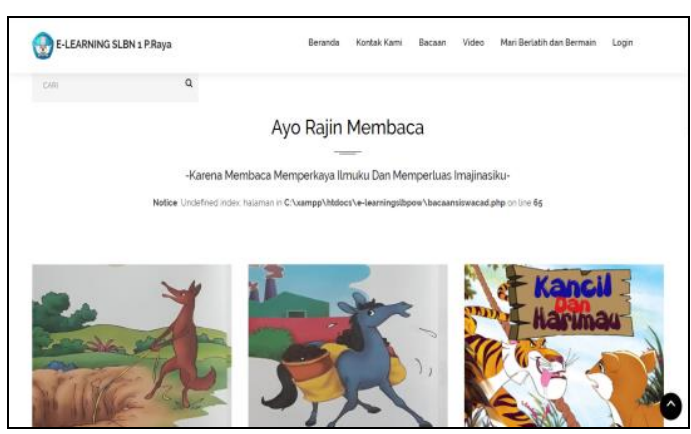

Gambar 7 Tampilan Halaman Bacaan Siswa

Dalam pengujian sistem ini digunakan metode Blackbox. Menurut Kevin (2016) Blackbox Testing atau yang sering dikenal dengan sebutan pengujian fungsional merupakan metode pengujian perangkat lunak yang digunakan untuk menguji perangkat lunak tanpa mengetahui struktur internal kode atau Program. Pengujian Blackbox dilakukan dengan membuat kasus yang 
bersifat mencoba semua fungsi dengan memakai perangkat lunak apakah sesuai dengan spesifikasi yang dibutuhkan. Berdasarkan pengujian Blackbox yang dilakukan pada e-learning berbasis website ini telah berjalan dengan baik dan berfungsi sesuai dengan spesifikasi yang didesain dan dibutuhkan sebelumnya.

\section{SIMPULAN}

Melalui penelitian E-Learning Berbasis Website pada SLBN 1 Palangka Raya ini dapat disimpulkan bahwa dalam merancang dan membangun website ini peneliti menggunakan metodologi pengembangan perangkat lunak Waterfall menurut (Sommerville, 2011).

Metode testing yang digunakan pada pembuatan website ini adalah Metode Blackbox. Pengujian ini dilakukan oleh sebanyak enam orang dimana setiap satu orang mewakili satu pengguna, yaitu super admin sebanyak satu orang, admin sebanyak satu orang, guru sebanyak satu orang, orang tua sebanyak satu orang, siswa sebanyak satu orang dan pengunjung sebanyak satu orang. Berdasarkan hasil pengujian blackbox ini dapat disimpulkan bahwa website ini dapat berfungsi sesuai dengan tujuan dan manfaat yang ingin dicapai.

\section{DAFTAR PUSTAKA}

Admi, 2018. 'Website E-Learning SLBN 1 Palangka Raya', Universitas Palangkaraya.

Alwinda, 2016. Rancang Bangun Media Pembelajaran Bahasa Korea Berbasis Website, Universitas Palangkaraya.

Arnesti, N. and Hamid, A., 2015. 'Penggunaan Media

Pembelajaran Online - Offline Dan Komunikasi Interpersonal Terhadap Hasil Belajar Bahasa Inggris', Jurnal Teknologi Informasi \& Komunikasi Dalam Pendidikan, 2(1).

Hartie, D, 2016. 'Psikologi Anak Berkebutuhan Khusus', Depdiknas, pp. 1-149.

Kevin, 2016. 'Institute Tutoring "Lely Study Club" E-Learning Website', Universitas Palangkaraya, pp. 1-11.

Sommerville, I, 2011. Software Engineering, Clinical Engineering: A Handbook for Clinical and Biomedical Engineers. 